\title{
Prospective study of ADHD cases with biological confirmation
}

\author{
Fabio de Almeida Bolognani
}

Federação Brasileira de Homeopatia, Rio de janeiro, Brazil

Introduction: Based on the large amount of patients that seek alternative treatment for clinical complaints compatible with ADHD diagnosis and above all by the high percentage of non adaptation or risk that officially proposed drugs may bring, we developed a laboratorial clinical investigative profile that favors a safe homeopathic treatment.

Material: 52 cases with urinary zinc analysis, with ADHD diagnosis.

Method: using the diagnosis confirmation questionnaire (SNAP-IV by UFRJ) and Zinc analysis by HPLC method (high performance liquid chromatography) which normal values range from 246 and $846 \mathrm{nmol} / \mathrm{liter}$.

Results: in a 52 patients (table 1) sampling with a suggestive ADHD diagnosis, we obtained a quantitative alteration in 31 cases showing high urinary Zinc levels, which allowed therapeutic approach that lead to better clinical result followed by subsequent reduction of urinary Zinc levels, in posterior analysis in eight (8) of these patients.

Table 1: 52 patients (table 1) sampling with a suggestive ADHD diagnosis

\begin{tabular}{|l|c|c|c|c|c|}
\hline & Standard & 1st exam & 2nd exam & 3rd exam & 4th exam \\
\hline & 266 / 846mcl / & & & & \\
\hline 1-Ayslan & & 1625 & 1211 & 2007 & 719 \\
\hline 2-Annie & & 3203 & & & \\
\hline 3-Bernardo & & 1113 & & & \\
\hline 4-Bruna & & 669 & & & \\
\hline 5-Bernardo S & & 1061 & & & \\
\hline 6-Erik & & 527.8 & & & \\
\hline 7-Estefania & & 3463 & & & \\
\hline 8-Gabriel & & 315 & & & \\
\hline 9-Gabriela & & 356.9 & & & \\
\hline 10-Italo & & 1442 & 181.1 & 309,5 & \\
\hline 11-Ian Jose & & 340.8 & & & \\
\hline 12-Igor & & 588 & & & \\
\hline 13-Iann & & 1836 & 646 & & \\
\hline 14-Isabel & & 982 & & & \\
\hline 15-Joao Lor & & 3871 & 2956 & 5590 & \\
\hline 16-Kaleb & & 2319 & & & \\
\hline 17-Leonora & 4704 & 2055 & 3424 & \\
\hline 18-Lara & & 857.9 & & & \\
\hline 19-Michel & & 7002 & 435 & & \\
\hline 20-Murilo & & 1400 & 3360 & 704.5 & \\
\hline 21-Matheus & & 4265 & & & \\
\hline 22-Maria Clara & & 953 & & & \\
\hline 23-Mateus & & 334 & & & \\
\hline 24-Paulo Henri & & 1004 & 905 & & \\
\hline 25-Pedro & & 433 & 166 & & \\
\hline 27-Nycole & & & & & \\
\hline 28-Pedro Ab & & & & & \\
\hline
\end{tabular}




\begin{tabular}{|l|c|c|c|c|c|}
\hline 29-Rodrigo Ch & & 1115 & & & \\
\hline 30-Rodrigo Ho & & 820 & & & \\
\hline 31-Rodrigo Lim & & 965 & 800 & & \\
\hline 32-Thiago Kres & & 212 & & & \\
\hline 33-Thales & & 1113 & 870 & 745 & \\
\hline 34-Thiago & 413 & & & \\
\hline 35-Warnei & 328.8 & & & \\
\hline 36-Waldemar & 1059 & & & \\
\hline 37-Thiago Lour & & 560.7 & 927 & 1585 & \\
\hline 38-Joao Vitor & 884,1 & & & \\
\hline 39-Pedro Henrique & & 1462,2 & & & \\
\hline 40-Ana Carolina Jardim & & 970 & 755 & & \\
\hline 41-Luan & & 456,3 & & & \\
\hline 42-Laura Merlim & & 1217,3 & & & \\
\hline 43-Joao Pedro Papa & & 282 & & & \\
\hline 44-Francisco V B Soares & & 436,3 & 370,2 & & \\
\hline 45-Thales Martoreli & & 1424 & 256 & & \\
\hline 46-Daniel Alves & & 928 & & & \\
\hline 47-Luiz Eduardo The & & 614,2 & & & \\
\hline 48-Daniel Silva & & 1091 & & & \\
\hline 49-Wagner Jardim & & 1133 & & & \\
\hline 50-Gustavo Maciel & & 1500 & 590 & 1100 & \\
\hline 51-Matheus Holanda & & 1551 & & & \\
\hline 52-Gabriel Oliveira & & & & & \\
\hline
\end{tabular}

Clinical results obtained in groups showing alteration in urinary zinc associated with subsequent evaluations, where introduction of Zincum mettalicum medication, at $12 \mathrm{CH}$, led to reduction in zinc values in urine and consequently clinical amelioration.

Other patients undergoing exams, which weren't included in subsequent evaluations, showed improvement, but since exams were executed in different laboratories other than the laboratory from the first analysis, weren't considered.

Patients numbers: 1,16 and 18 (table 2) demonstrated a raise in urinary zinc levels from second to third analysis. These patients stopped using their homeopathic medications for at least 30 days (during school vacation), which lead to this increase but when reintroducing the medication, these rates lowered to normal levels again.

Table 2: Patients with a raise in urinary zinc levels from second to third analysis.

\begin{tabular}{|l|l|c|c|c|c|}
\hline 18-Lara & & 4704 & 2055 & 3424 & 1338 \\
\hline 16-Kaleb & & 3871 & 2956 & 5590 & 378 \\
\hline 1-Ayslan & & 1625 & 1211 & 2007 & 719 \\
\hline
\end{tabular}

\section{Comments:}

Treatment of this clinical condition places the homeopathic doctor in different situations according to legislations and rules for medical procedures.

Some countries consider that from Attention Deficit Hyperactivity Disorder diagnosis, the use of specific medications is mandatory, and its use will be restricted only in cases where its use leads to harm. 
Homeopathic doctors also encounter difficulties with these patients, since medications even while being appropriate; do not always offer safety of lasting clinical results.

Alterations in human body led by Zinc element, when unstable, due to environmental phenomena, could justify the concept of "epidemic gene" since symptoms and origins demonstrate susceptible population of considerable proportion.

Attention to hygiene and food habits are the main issues approached, but habits and food availability in each population can determine incidence and re-incidence of this clinical phenomenon. Why?

\section{People without diagnose of TDAH}

1- Suelene Dias Silva 153

2- Leo Pereira Silva 485

3- Erik Pereira $\quad 760,1$

4- Angelo Pereira 302

5- Angela Bazzanela 736

6- Sonia Palombini 264

7- Paulo C Gomes $\quad 502,7$

8- Larissa Primo $\quad 555$

9- Lara Salles 332

10- Robert Vieira $\quad 670,6$

\section{Zincum Mettalicum:}

- in metabolism of over 100 enzymes, and interferes in hormone functioning, protein synthesis, reproduction and immunological system.

- Recent article, published in Nature Reviews, Neuroscience, November 2009/ volume 10, by Sensi ( University G. d'Annunzio-Italy and University of California-USA), Paoletti ( Centre National de Recherche-Paris-France), Bush (University of Melbourne-Australia) and Sekler ( Ben Gurion University-Israel), revels that in the brain, zinc in its ionic form ( $\mathrm{Zn} 2+)$ is highly enriched at many but not all glutamatergic nerve terminals, is released upon neuronal activity and is crucial to the control of physiological and pathophysiological brain functions.

This Zinc, is estimated to rise to micromolecular levels in the proximity of axon terminals following release from synaptic vesicles that contain millimolar (Zn2+).

Synaptically released $\mathrm{Zn} 2+$ interacts with various neuronal ion channels, receptors and transporters and therefore modulates synaptic transmissions and plasticity.

$\mathrm{Zn} 2+$ affects the activity of NMDA (N-methyl-D-aspartate) and GABA ( y-amino butyric acid type A) receptors, thereby influencing excitatory synaptic transmission in the brain.

Besides its physiological functions, $\mathrm{Zn} 2+$ is also a potent toxin that is involved in neuronal and glial death and is associated with a variety of excitotoxic conditions, such as epilepsy, ischeaemic and brain trauma. Finally, a major role for $\mathrm{Zn} 2+$ has been suggested in the neurodegeneration associated with Alzheimer's disease, as it is a key component of amyloid plaques and the cerebral amyloid angiopathy observed in Alzheimer's disease.

The best studied $\mathrm{Zn}$ transporter in the bain, is mainly localized at $\mathrm{Zn} 2+$ containing synaptic glutamatergic vesicles in the hippocampus, cortex and olfactory bulb, and is also present in certain cerebella GABAergic and 
dopaminergic neurons and in specific locations of the spinal cord. Others studies revels the fact that severe Zn2+ deficiency, caused by diet or chelation, enhances susceptibility to seizures.

The functional relevance of such sophisticated Zn2+ homeostatic machinery that controls the balance of $\mathrm{Zn} 2+$ concentrations between synaptic and somatic compartments of neurons is underlined by the emerging role of $\mathrm{Zn} 2+$ in the modulation of brain functioning.

Many glutamatergic vesicles in certain brain regions (neocortex, amygdale and hippocampus) contain high concentrations of $\mathrm{Zn} 2+$, suggesting that it has a role in cognition and synaptic plasticity. There are strong evidences that Zn2+ truly acts as a co-transmitter at many Central Nervous System synapses and participates in synaptic plasticity, and some kinds of experiences can show tremors, delayed righting reflex, abnormal gait and exaggerated startle responses in mices.

Further evidence for a modulatory role of $\mathrm{Zn} 2+$ in long term potentiation comes from recordings of hippocampus CA3 mossy fiber synapses, the most Zn2+ enriched synapses in the brain. At these synapses, extracellular Zn2+ may be present in a tonic fashion at low (probably nanomolar) levels, whereas levels can increase transiently during action potential driven exocytosis..

- It is widely present in pancreas, liver, skin and annexes.

- Some substances, such as PHYTATES, found in high fiber vegetables, as well PHYTALATES (polyvinyl chloride packages), alcohol, tannins, antibiotics (ampicillin), corticosteroids and contraceptives, inhibit dietary zinc absorption, or accelerates its elimination in conditions such as cirrhosis, renal illnesses, etc.

At this phase, we establish a relationship with Bisphenol-A, known as one of the most common environmental endocrine disrupter, that has been extensively evaluated for toxicity in a variety of tests in rodents, including developmental and reproductive toxicity, and carcinogenicity. However, in the report of Prenatal and neonatal exposure to Bisphenol-A, (Neuroscience 2003 / 117, by Suzuki, Nakazawa, Funae, Fukushima, Narita, from Departement of Toxicology, School of Pharmacy and Pharmaceutical Sciences-TokioJapan), show that prenatal and neonatal exposure to BPA in mice leads to enhancement of dopamine D1 receptor-dependent rewarding effect induced by a psycho stimulant methamphetamine. Furthermore, this treatment with BPA markedly enhanced hyper locomotion and its sensibilization induced by methamphetamine, which reflects extensive abuse associated with sociological and psychiatric problems.

In other report, Prenatal phthalate exposure and performance on the Neonatal Behavioral assessment scale, Neurotoxicology/2009/30, by Engel, Zhu, Berkowitz, Calafat, Silva , Wolff, from Mount Sinai School of Medicine-New York-USA), the relationship between prenatal urinary concentrations of phthalate metabolites and neonatal behavior in 295 children, that received by trained examiners the Brazelton Behavioral Assessment Scale. Seven phthalate esters metabolites were evaluated.

The result, among girls, there was a significant linear decline in adjusted mean Orientation score with increasing urinary concentrations of high molecular weight phthalate metabolites. Likewise, there was a strong linear decline in their adjusted mean Quality of Alertness score. In addition, boys and girls demonstrated opposite patterns association between low and high molecular weight phthalate concentrations and motor performance, with increasing concentration of low molecular weight phythalate metabolites among boys.

Janet Raloff, report in Science News, November/2009, the study of Bruce Lanphear, of Simon Fraser University in Burnaby-British Columbia. BPA in the womb shows link to kid's behavior, linked prenatal exposure to BPA with subtle, gender-specific alterations in behavior among two years olds. Girls whose mothers had encountered the most BPA early in pregnancy tended to become somewhat more aggressive 
than normal, boys became more anxious and withdrawn. BPA, a common ingredient in hard polycarbonate plastics and resins used in food-can linings. Braun, in his paper in Environmental Health Perspectives, report that the higher a mom's BPA levels were during her first 16 weeks of pregnancy, the more likely her child was to later show behavior somewhat atypical of its gender. Braun report that the mannish girls and feminized boys, are more due a production or action of their gender-establishing sex hormones might have been blocked.

Girls whose mothers had the highest BPA exposures in early pregnancy tended to score high on the externalizing component of a test known as BASC-2, for Behavioral Assessment System for Children-2. It's geared to young children and evaluates their tendency towards aggression and hyperactivity.

Boys with the highest womb exposures to BPA tended to exhibit an increase internalizing BASC-2 score. They were more likely to be withdrawn or show depressive symptoms, or maybe complain about aches and pains, which is often a manifestation of anxiety.

- Neurological syndromes:

- Physical asthenia, physical and psychic asthenia: depletion, dejection, and depression.

- Intellectual, physical and sexual asthenia.

- Slow comprehension, obnubilation,

- Slow, but impatient and irritated

- Intolerant to noises and conversations

- Sensorial hyperesthesia

- Insomnia with constant movement of legs and feet, fright, screams during sleep, wakes up frightened

- Constant agitation of inferior members, especially when seated

- When lays down to sleep, legs won't stop and prevents from sleeping

- Enhances tendinous reflexes

- Spasms, tremor, contractures, myoclonia

- Convulsion, chorea, epilepsy

- Lack of neuro muscular coordination

- Urinary retention

- Incontinence

- All nervous pathologies, benign or chronic, following brutal retrogress or repression of infectious or eruptive disease, or associated with the use of corticosteroids, antibiotics, antidepressants, neuroleptic drugs, tranquilizers.

It would be possible that repulsion towards food from vegetal group, especially with more fibers that are common to children would be a form of "self" prophylaxis?

Food and beverage stored in polyvinyl packages, which is normally not perceived by basic human instincts, do not find the same resistance by human body?

Abuse of antibiotic and corticosteroid treatment usually seen today may take part in this alteration? Would alterations in digestive tract be important?

Meanwhile, results from this study suggest that association of Zincum mettalicum, might regulate what seems to be a greater loss of this element in urine, since blood analysis did not alter, which apparently corroborated the hypothesis of absorption of zinc being correct, reducing urinary loss. 


\section{Bibliography:}

ADAMS R., VICTOR M., ROPPER A., - Principles of Neurology, New York, International Edition, 1997.

ALLEN, T.F. - The Encyclopedia of Pure Materia Medica, New Delhi. B. Jain Publishers, 990, vol II.

ARIOVALDO, R.F. - Novo Repertório de Sintomas Homeopáticos, São Paulo. Robe Editorial, 1996.

BLACKWOOD, A. L. - Materia Medica Terapeutica y Farmacologia Homeopatica. B. Jain Publishers.

CONAN MERIADEC, L’ Homeopathie, 1990, Paris, Editions Boiron

CARILLO, R., Fundamentos da Homeopatia Constitucional, 1007, São Paulo, Santos editora

CAIRO, N. - Guia de Medicina Homeopática, São Paulo. Livraria Teixeira, 1976.

CLARCKE, J.H. - Dictionary of Practicas Materia Medica, New Delhi. Jain Publishing Co, 1983, vol II.

COSTA, A.F. - Farmacognosia, Lisboa. Fundação Calouste Gulbenkian, 1987.

DELLIERE, M., PASQUIER, A., Homeopathie et Sport, 2006, Marabout

DEMARQUE, D., JOUANNY, J., POITEVIN, B., SAINT-JEAN, Y., Homeopathie connaitre la Matiere Medicale, Paris, 1989, CEDH

FLEHMIG, I. - Desenvolvimento normal e seus desvios no lactente, Rio de Janeiro.

Atheneu, 1982.

GILMAN, A.G.; GOODMAN, L.S.; GILMAN, A. - As Bases Farmacológicas da Janeiro. 1985.

Terapêutica, Rio de

GUERMONPREZ, M. Matiere Medicale Homeopathique, Paris, 1985, Doin

HAGER - Tratado de Farmácia Práctica, Barcelona. Editorial Labor, 1942, tomo II.

HAHNEMANN, C.S.F. - Matéria Médica Pura, São Paulo. Editorial Homeopática $\quad$ Brasileira, 1998.

HAHNEMANN, C.S.F. - Organon da Arte de Curar, São Paulo. GEHSP “Benoit $\quad$ Mure”, 1995.

HAMILTON, E.M.D. - The Flora Homoeopathica, New Delhi. B. Jain Publishers, 1995.

HERING, C.M.D. - The guiding Symptons of our Materia Medica, New Delhi. B. Jain Publishers, 1993, vol III.

HODIAMONT, g., Homeopathie et Physiologie, 1983, Paris, J.B. Bailliers

HUGLES, R. - A Manual of Pharmacodynamics, New Delhi. B. Jain Publishers, 1994.

LUNDY-EKMAN, L., Neurociencia, 2002, EUA, Elsevier

KENT, J.T. - Materia Medica Homeopatica, Buenos Aires. Editorial Aebatros, 1980, tomo II.

KOLLITSCH, P. - Matière Médicale Therapeutique, Paris. Livrairie Maloene, 1955.

NELSON - Textbook of Pediatrics, Philadelphia, London, Toronto. Vaughan and Mckay, 1975. 
RHODE, MATTOS, Principios e Pratica em TDAH, Atmed Editora, 2003, Porto Alegre, Brasil

SCHIMDT, Neurofisiologia, 1979, São Paulo, Editora Pedagogica Universitaria

SENSI, PAOLETTI, BUSH, SEKLER, Zinc in the physiology and pathology uf the CNS, Nature Reviews, November 2009, volume 10, Macmillan Publishers Limited

TETAU, M., Bergeret, C., L’ Organotherapie diluee et dynamisee, Paris, 1984, Maloines

TYLER, M.L. - Retratos de Medicamentos Homeopáticos, São Paulo. Livraria Editora Santos, 1992.

VIJNOVSKY, B. - Tratado de Materia Medica Homeopatica, Buenos Aires. 1992, tomo II.

VOISIN, H. - Manual de Matéria Médica para o Clinical Homeopata, São Paulo.

Editora, 1984.

ZISSU, R.- Matiere Medicale Homeopathique Constitutionelle, Paris, 1977, Librairie Le François,

(c)) BY-NC-ND Licensed to GIRI

Support: authors declare that this study received no funding

Conflict of interest: authors declare there is no conflict of interest

Correspondence author: Fabio de Almeida Bolognani, fabiobolognani@gmail.com, www.homeopatiabrasil.org.br

How to cite this article: Bolognani FA. Prospective study of ADHD cases with biological confirmation. Int J High Dilution

Res [online]. 2011 [cited YYYY Month dd]; 10(35): 84-90. Proceedings of the XXIV GIRI Symposium; 2010 Nov 05; Monte

Carlo (Monaco). GIRI; 2010. [cited YYYY Month dd]; Available from:

http://www.feg.unesp.br/ ojs/index.php/ijhdr/article/view/443/475 